\title{
Prediction of Disseminated Intravascular Coagulation in Patients with Leukemia
}

\author{
Miyuki NaItoh, Kiyoshi Andoh, Hiroto Sadakata, Hiroshi TanaKa and Norio Kobayashi
}

In 43 patients with leukemia, we determined the increase of tissue factor (TF) activity production by leukemic cells that was induced by incubation with endotoxin at the time of admission. Definite disseminated intravascular coagulation (DIC) developed in 8 patients on admission (Group III) and in 8 patients just after the initiation of treatment (Group II), but not in the remaining 27 patients (Group I). TF activity before incubation (TF1) was $0.70 \mathrm{U} / 10^{8}$ cells or more in 6 patients of Group III, while it was less in all the patients of Group II and 25 of the 27 patients of Group I. On the other hand, TF activity after incubation with endotoxin (TF2) increased to more than $1.11 \mathrm{U} / 10^{8}$ cells in all the patients of Groups II and III, while it remained less in all the patients of Group I. These results suggest that the leukemic cells in Group II might not have expressed sufficient TF activity to cause DIC until chemotherapy was begun, and that $1.11 \mathrm{U} / 10^{8}$ cells or more of TF2 might strongly indicate the development of DIC during treatment for leukemia.

(Internal Medicine 33: 131-135, 1994)

Key words: tissue factor activity, DIC

\section{Introduction}

Disseminated intravascular coagulation (DIC) develops in patients with a variety of malignant diseases, and is likely to be triggered by the procoagulant activity released from tumor cells $(1,2)$. DIC tends to be aggravated by chemotherapy, and this may adversely affect the prognosis. Acute leukemia is the most representative malignancy in which DIC readily occurs (3). In acute leukemia, the trigger of DIC has been identified as a procoagulant activity known as tissue factor (TF), which is present in leukemic cells (4-7). TF activity can be measured in virtually all leukemia patients by a simple clotting assay using bone marrow cells $(2,8)$. We have reported previously that the severity of DIC in patients with acute leukemia is correlated to the TF activity of bone marrow cells on admission (9).

Lyberg and associates (10) divided cells into three categories with respect to $\mathrm{TF}$ production: 1] cells constitutively synthesizing apoprotein III, and thus TF, e.g., mouse placental trophoblasts, 2] cells in which the synthesis of apoprotein III is inducible by various exogenous stimuli, e.g., monocytes and macrophages, and 3] cells that do not synthesize apoprotein III under any experimental conditions hitherto tested, e.g., granulocytes and lymphocytes. In our above-mentioned study, leukemic cells belonging to the first or third categories, but not to the second one, were investigated. Human cultured leukemic cell lines have been reported to show induction of TF production in response to various stimuli, e.g., cytotoxic drugs and endotoxin $(11,12)$. In the present study, in order to investigate leukemic cells mainly belonging to the second category, we assessed the response of leukemic cell TF activity to endotoxin in 43 patients with various types of leukemia, and evaluated the clinical implications with regard to the development of DIC.

\section{Materials and Methods}

\section{Patients (Table 1)}

Forty-three patients with various types of leukemia were managed with combination chemotherapy at the medical ward of Gunma University Hospital between 1987 and 1990. The patients ranged in age from 16 to 86 years (mean \pm SD: $46.5 \pm 23.0$ years), and included 29 men and 14 women. The diagnoses were based on morphologic and cytochemical studies (3, 1318).

\section{Heparin treatment}

In accordance with the recommendation of the attending

From the Third Department of Internal Medicine, Gunma University School of Medicine, Maebashi

Received for publication July 14, 1993; Accepted for publication January 6, 1994

Reprint requests should be addressed to Dr. Miyuki Naitoh, the Third Department of Internal Medicine, Gunma University School of Medicine, 3-39-15, Showacho, Maebashi, Gunma 371 


\section{$\mathrm{NAITOH}$ et al}

Table 1. Clinical Profile of the Leukemia Patients

\begin{tabular}{lccccccc}
\hline Diagnosis of leukemia & AML (APL) & ALL & CML & CML-BC & CLL & CMMoL-BC & Total \\
\hline $\begin{array}{l}\text { Number of Pts. } \\
\text { Age in years }\end{array}$ & $21(3)$ & 6 & 4 & 8 & 3 & 1 & 43 \\
$\begin{array}{l}\text { Number of Pts. with DIC } \\
\begin{array}{l}\text { a) on admission } \\
\text { b) after initiation } \\
\text { of chemotherapy }\end{array}\end{array}$ & $6(3)-83$ & $16-65$ & $36-71$ & $22-61$ & $54-65$ & 86 & $16-86$ \\
\hline
\end{tabular}

AML: acute myelogenous leukemia, APL: acute promyelocytic leukemia, ALL: acute lymphocytic leukemia, CML: chronic myelogenous leukemia, CML-BC: CML in blast crisis, CLL: chronic lymphocytic leukemia, CMMoL-BC: chronic myelomonocytic leukemia in blast crisis, DIC: disseminated intravascular coagulation.

physicians, 17 patients were treated with a continuous intravenous infusion of heparin $(15,000-25,000$ units (U)/day). The activated clotting time (AcCT) was used to monitor heparin therapy, with the therapeutic range set as 130-200 sec (normal: $50-90 \mathrm{sec}$ ). Patients received platelet transfusions as needed to maintain a platelet count of $>20,000 / \mu \mathrm{L}$, but fresh-frozen plasma was not administered.

\section{Diagnosis of DIC}

The following routine tests were performed immediately after admission: prothrombin time, plasma fibrinogen concentration, and serum fibrin/fibrinogen degradation products (FDP) concentration. DIC was diagnosed using the criteria shown in Table 2, which were based on a scoring system proposed by the Research Committee on DIC in Japan (19). A definite diagnosis of DIC required a total DIC score of 4 or more.

\section{Preparation of test samples}

Prior to remission induction chemotherapy, leukemic cells were prepared from bone marrow aspirates by differential centrifugation and hypotonic lysis in $0.225 \% \mathrm{NaCl}$ for $30 \mathrm{sec}$. The cells were resuspended at a concentration of $1 \times 10^{7} / \mathrm{mL}$ in RPMI-1640 medium (GIBCO, Grand Island, NY) and were cultured with $0.1 \mu \mathrm{g} / \mathrm{mL}$ endotoxin (EDX; Escherichia coli $055: \mathrm{B} 5)$ at $37^{\circ} \mathrm{C}$ in $5 \% \mathrm{CO}_{2} / 95 \%$ air. After incubation for 0 or 3 hours, the cells were rinsed twice with $2.0 \mathrm{~mL}$ of Hanks' balanced salt solution, resuspended in $1.0 \mathrm{~mL}$ of veronal buffer, and homogenized with a Potter-Elvehjem homogenizer at 1,000

Table 2. Diagnostic Criteria for DIC

\begin{tabular}{lcccc}
\hline Points scored & 0 & 1 & 2 & 3 \\
\hline Leukemia & No & Yes & - & - \\
$\begin{array}{l}\text { Organ dysfunction } \\
\text { due to DIC }\end{array}$ & No & Yes & - & - \\
PT $(\mathrm{sec})$ & $<15$ & $\geq 15 \&<20$ & $\geq 20$ & - \\
$\quad$ or PT ratio & $<1.25$ & $\geq 1.25 \&<1.67$ & $\geq 1.67$ & - \\
Plasma Fbg level $(\mathrm{mg} / \mathrm{dL})$ & $>150$ & $\leq 150 \&>100$ & $\leq 100$ & - \\
Serum FDP level $(\mu \mathrm{g} / \mathrm{mL})$ & $<10$ & $\geq 10 \&<20$ & $\geq 20 \&<40$ & $\geq 40$ \\
\hline
\end{tabular}

PT: prothrombin time, Fbg: fibrinogen, FDP: fibrin(ogen) degradation products.
2,000 rpm for 1 to $2 \mathrm{~min}$. Cells incubated for 0 and 3 hours were designated as samples A and B, respectively.

\section{TF activity assay}

The TF activity of samples A and B was measured by the one-stage clotting assay as follows: $0.1 \mathrm{~mL}$ of the homogenate and $0.1 \mathrm{~mL}$ of factor IX-deficient plasma were incubated for 3 min at $37^{\circ} \mathrm{C}$, after which $0.1 \mathrm{~mL}$ of $25 \mathrm{mmol} / \mathrm{L} \mathrm{CaCl}_{2}$ solution was immediately blown into the mixture to determine the clotting time. The activity which gave $14 \mathrm{sec}$ of clotting time was arbitrarily defined as $100 \mathrm{U} / 10^{8}$ cells $(8,9,20)$, and that which gave clotting time longer than $240 \mathrm{sec}$ was defined as absent. The procoagulant activity of the same samples was also assayed using factor X-deficient plasma using the same procedure.

\section{Statistical evaluation}

Mean values with standard deviation for each group were compared using the Student's t-test.

\section{Results}

\section{Development of DIC (Table 1)}

Based on the DIC scores obtained on admission $\left(\mathrm{D}_{1}\right)$ and the maximum DIC scores after the initiation of chemotherapy $\left(D_{\max }\right)$, the 43 patients were divided into the following 3 groups: Group I $\left(\mathrm{D}_{1} \leq 3, \mathrm{D}_{\max } \leq 3\right), 27$ patients in whom DIC did not develop; Group II $\left(D_{1} \leq 3, D_{\max } \geq 4\right), 8$ patients in whom definite DIC developed after starting treatment for leukemia; and Group III $\left(\mathrm{D}_{1} \geq 4, \mathrm{D}_{\max } \geq 4\right), 8$ patients in whom definite DIC was present on admission.

\section{Response of leukemic cell TF production to endotoxin}

When the leukemic cells obtained from the 43 patients were cultured with endotoxin, the procoagulant activity generated during incubation enhanced the clotting time of factor IXdeficient plasma, but not that of factor X-deficient plasma.

\section{A) Before culture with endotoxin (Fig. 1)}

Cells from 13 of the 27 patients in Group I had no TF activity before culture. In the remaining 14 patients, the log value of TF activity (TF1) ranged from 0.15 to $0.88 \mathrm{U} / 10^{8}$ cells. The cells 
a)

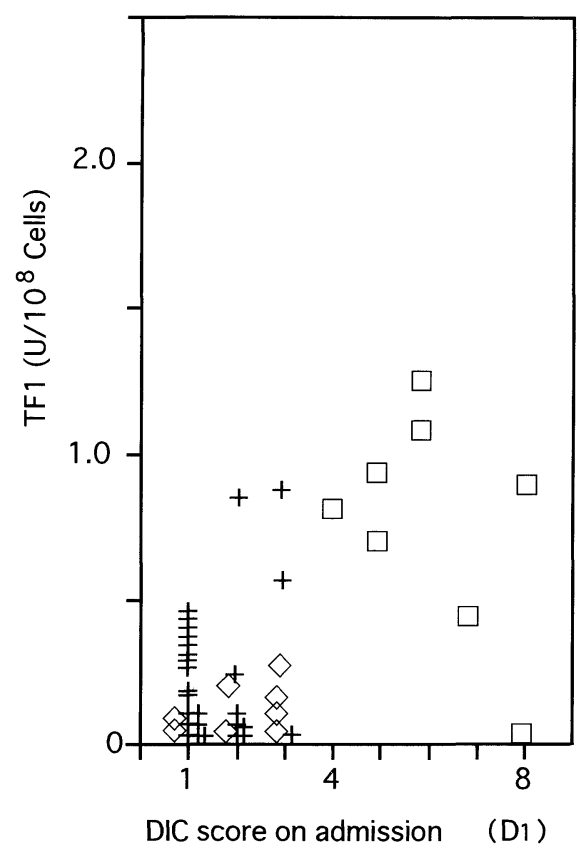

b)

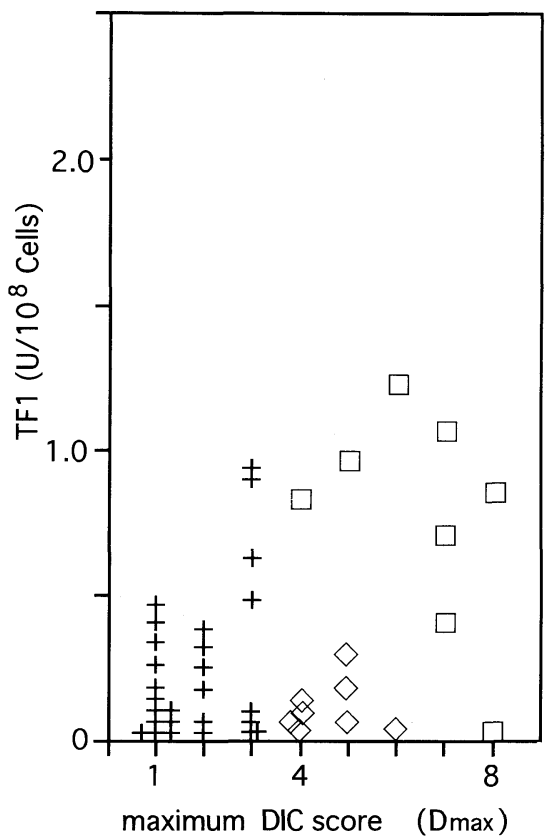

Fig. 1. TF activity in leukemic cells (TF1) and development of DIC. a) Correlation between log value of TF activity before culture with endotoxin (TF1) and DIC score on admission $\left(D_{1}\right)$. b) Correlation between TF1 and maximum DIC score $\left(\mathrm{D}_{\max }\right) .+$ : Group I patients (no DIC), $\diamond$ : Group II patients (definite DIC developed after starting chemotherapy), $\square$ : Group III patients (definite DIC was present on admission). TF activity: tissue factor activity, TF1: $\log$ value of TF activity before culture with endotoxin, DIC: disseminated intravascular coagulation, $\mathrm{D}_{1}$ : DIC score on admission, $\mathrm{D}_{\max }$ : maximum DIC score.

from 6 of the 8 patients in Group II had no TF activity, while in the other $2 \mathrm{TF} 1$ was 0.18 and $0.23 \mathrm{U} / 10^{8}$ cells, respectively. In Group III, the cells from all but one patient had TF activity and $\mathrm{TF} 1$ ranged from 0.40 to $1.22 \mathrm{U} / 10^{8}$ cells. The mean value with standard deviation (SD) of TF1 in Group III $\left(0.74 \pm 0.39 \mathrm{U} / 10^{8}\right.$ cells) was significantly higher than in Groups II $(0.05 \pm 0.10 \mathrm{U} /$ $10^{8}$ cells, $\left.\mathrm{p}<0.01\right)$ and $\mathrm{I}\left(0.21 \pm 0.26 \mathrm{U} / 10^{8}\right.$ cells, $\left.\mathrm{p}<0.01\right)$, and the mean value in Group II was significantly lower than that in Group I ( $\mathrm{p}<0.05)$.

In all 43 patients, TF1 was correlated more strongly with the $\mathrm{D}_{1}$ value $(\mathrm{r}=0.52, \mathrm{p}<0.01)$ than with $\mathrm{D}_{\max }(\mathrm{r}=0.40, \mathrm{p}<0.01)$.

\section{B) After culture with endotoxin (Fig. 2)}

Cells from all patients in Groups II and III showed TF activity after culture. The log value of TF activity after culture (TF2) was 1.17-2.00 (mean: $1.58 \pm 0.31) \mathrm{U} / 10^{8}$ cells in Group II and 1.11-1.71 (mean: $1.40 \pm 0.20$ ) $\mathrm{U} / 10^{8}$ cells in Group III. There was no significant difference in the mean value between Groups II and III ( $\mathrm{p}>0.05)$.

In Group I, the cells from 3 patients had no TF activity after culture. In the others, TF2 was $0.20-1.08$ (mean: $0.61 \pm 0.34$ ) U/ $10^{8}$ cells, with all of them showing less TF activity than the minimum level in Groups II and III (1.11 U/10 $0^{8}$ cells).

In all 43 patients, TF2 was correlated more strongly with $\mathrm{D}_{\max }(\mathrm{r}=0.77, \mathrm{p}<0.01)$ than with $\mathrm{D}_{1}(\mathrm{r}=0.52, \mathrm{p}<0.01)$.

\section{Leukemic cell count and DIC}

Leukemic cell counts in peripheral blood were 3.99 \pm $4.14 \times 10^{4} / \mu \mathrm{L}$ in Group I, $6.14 \pm 3.26 \times 10^{4} / \mu \mathrm{L}$ in Group II and $5.01 \pm 4.72 \times 10^{4} / \mu \mathrm{L}$ in Group III, respectively. Those in bone marrow were $25.13 \pm 19.71 \times 10^{4} / \mu \mathrm{L}$ in Group I, $51.76 \pm$ $58.84 \times 10^{4} / \mu \mathrm{L}$ in Group II and $37.03 \pm 30.67 \times 10^{4} / \mu \mathrm{L}$ in Group III, respectively. Not only in peripheral blood but also in bone marrow, there were no significant differences in the leukemic cell counts between the three groups ( $>0.05$ ).

\section{Discussion}

In various malignant diseases other than leukemia, it is difficult to obtain tumor cells that are triggering DIC on admission. Consequently, various results, but not the cause, of DIC have been generally investigated. This might be the reason why a prediction method for DIC has not yet been established. However, in leukemia, it is usually easy on admission to obtain leukemic cells from a patient and to measure its TF activity. Therefore, to predict DIC immediately and precisely, we have studied the TF activity of leukemic cells in correlation with DIC development in leukemia patients $(2,7-9,11)$.

To measure TF activity, we originally used the two-stage clotting assay of Nemerson with slight modifications (20), because the one-stage clotting assay using normal plasma as a 
c)

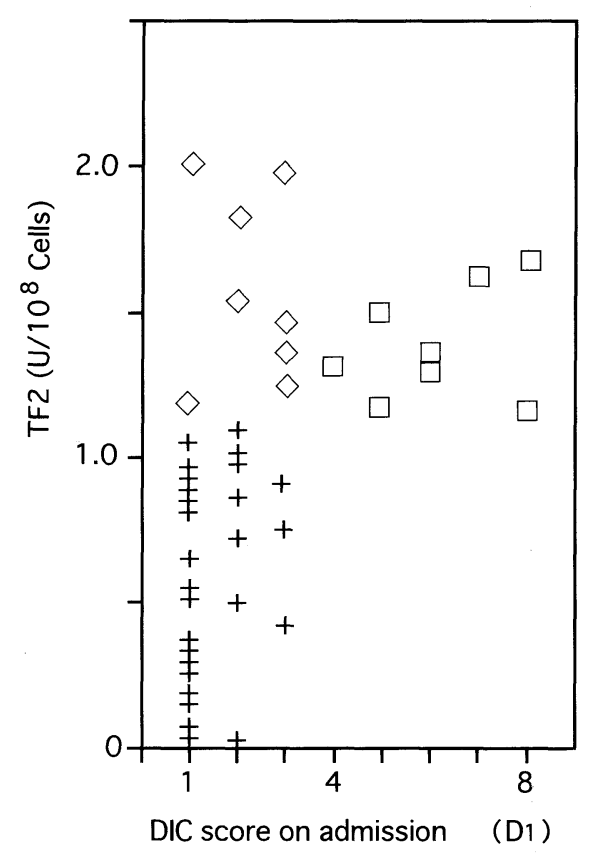

d)

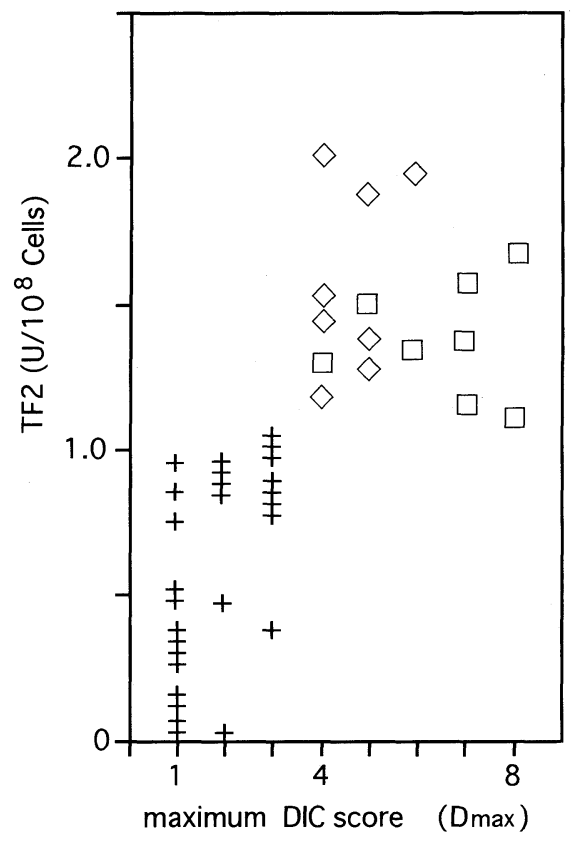

Fig. 2. Response of TF activity to endotoxin and development of DIC. c) Correlation between log value of TF activity after culture with endotoxin (TF2) and DIC score on admission $\left(\mathrm{D}_{1}\right)$. d) Correlation between TF2 and maximum DIC score $\left(\mathrm{D}_{\max }\right) .+$ : Group I patients (no DIC), $\diamond:$ Group II patients (definite DIC developed after starting chemotherapy), $\square$ : Group III patients (definite DIC was present on admission). TF activity: tissue factor activity, TF2: $\log$ value of TF activity after culture with endotoxin, DIC: disseminated intravascular coagulation, $\mathrm{D}_{1}$ : DIC score on admission, $\mathrm{D}_{\max }$ : maximum DIC score.

substrate may reflect the activity of both the extrinsic and intrinsic pathways of blood coagulation. However, the twostage clotting assay may not be appropriate for the routine clinical setting because of its complexity. Therefore, we have previously assessed the usefulness of the one-stage clotting assay with factor IX-deficient plasma instead of normal plasma in order to block the influence of the intrinsic pathway on the clotting time. We found that the one-stage clotting assay using factor IX-deficient plasma was sufficiently sensitive to accurately measure as little as $0.03 \mathrm{U} / \mathrm{ml}$ of TF activity with a high reproducibility (8). In the present study, the procoagulant activity generated in response to incubation with endotoxin enhanced the clotting time of factor IX-deficient plasma, but not that of factor X-deficient plasma. This indicated that the procoagulant activity generated by leukemic cells was $\mathrm{TF}$ activity, and was neither a direct prothrombin activator nor a direct activator of factor X, substances which have been reported to be synthesized by endotoxin-stimulated macrophages $(21,22)$.

We have previously shown that the severity of DIC in patients with acute myelogenous leukemia is significantly related to the TF activity of their leukemic cells, but not to the leukemic cell counts in peripheral blood and bone marrow (7, 9). Among the three groups in the present study, no significant difference was observed in the leukemic cell counts at all. This could be expected because the number of leukemic cells in a patient with overt leukemia is around $1 \times 10^{12}$.

DIC in patients with leukemias is especially common after the initiation of chemotherapy due to the abrupt release of TF activity from the leukemic cells $(2,3)$. We have already shown that production of TF activity can be induced in human leukemic cell lines by endotoxin $(12,23)$. In the present study, to estimate the potency of leukemic cells to induce the TF activity which may cause DIC, we stimulated leukemic cells with endotoxin for 3 hours and measured the TF activity before (TF1) and after stimulation (TF2).

TF1 was $0.70 \mathrm{U} / 10^{8}$ cells or more in $75 \%$ of the patients who had already had DIC on admission (Group III), while it was less than $0.70 \mathrm{U} / 10^{8}$ cells in all the patients who developed DIC just after starting chemotherapy (Group II) and in $93 \%$ of the patients who were free from DIC (Group I). Compared with Group I, the mean value of TF1 was significantly lower in Group II. These results indicated that the exact prediction of the risk of DIC after starting treatment would be difficult on the basis of TF1 alone. On the other hand, TF2 reached $1.11 \mathrm{U} / 10^{8}$ cells or more in all the patients of Groups II and III, while it remained less than $1.11 \mathrm{U} / 10^{8}$ cells in all Group I patients. There was no significant difference in the mean value of TF2 between Groups II and III. From these results, it was suggested that the leukemic cells in Group II may not have expressed 
sufficient TF activity to cause intravascular coagulation until the start of chemotherapy, whereas those in Group III were already producing the activity on admission and those in Group I failed to express the activity throughout the observation period. Therefore, it seems that leukemic cells can be divided into the following three categories: 1] cells like those in Group I that produce insufficient TF activity to induce DIC, 2] cells like those in Group II which show a sufficient increase of TF activity expression to induce DIC during treatment of leukemia, and 3] cells such as those in Group III with sufficient constitutive production of TF activity to cause DIC. Measurement of TF1 and TF2 on admission enables to distinguish leukemic cells in the second category from those in the first and third categories. In addition, TF1 was correlated more significantly with $D_{1}$ than with $D_{\max }$, indicating that the severity of DIC on admission was related to intrinsic TF activity production by the leukemic cells. On the contrary, TF2 correlated more significantly with $D_{\max }$ than with $D_{1}$, suggesting that the aggravation of DIC after the initiation of treatment was strongly related to extrinsic TF activity production by the leukemic cells. Furthermore, TF2 showed much stronger correlation with $\mathrm{D}_{\max }$ than TF1 did. This confirms our suggestion that the estimation of TF2 should facilitate precise prediction of the development of DIC during treatment for leukemia.

To control DIC better, the diagnosis of leukemia should be made as promptly as possible and the risk of DIC should be predicted by the estimation of TF2 immediately after admission. Once TF2 reaches $1.11 \mathrm{U} / 10^{8}$ cells or more, greater attention to DIC development should be paid during treatment for leukemia.

Acknowledgements: This study was supported in part by research grants for Intractable Disease and Cardiovascular Disease from the Ministry of Health and Welfare of Japan, and by a grant-in-aid for Scientific Research on Priority Areas from the Ministry of Education, Science, and Culture of Japan. We wish to thank Dr. Hidemi Gonmori and Dr. Tadashi Maekawa for their helpful advice. Acknowledgement is also due to the doctors working in the medical ward of Gunma University Hospital for their understanding and careful attention to the protocol for DIC management.

\section{References}

1) Marder VJ. Consumptive Thrombohemorrhagic Disorders. in: Hematology, Williams WJ, Beutler E, Erslev AJ, Lichtman MA, Eds. McGraw-Hill, New York, 1990, p. 1522.

2) Gonmori H, Maekawa T, Kobayashi N, Tanaka H, Takada M, Andoh K. The Role of Tissue Thromboplastin in the Development of DIC Accompanying Neoplastic Diseases. in: Disseminated Intravascular Coagulation, Abe T, Yamanaka M, Eds. University of Tokyo Press, Tokyo, 1983, p. 23.

3) Henderson ES. Acute Leukemia: General Considerations. in:Hematology,
Williams WJ, Beutler E, Erslev AJ, Lichtman MA, Eds. McGraw-Hill, New York, 1990, p. 236.

4) Quingley HJ. Peripheral leukocyte thromboplastin in promyelocytic leukemias. Federation Proceedings 26: 648, 1967 (Abstract).

5) Gouault-Heilmann M, Chardon E, Sultan C, Josso F. The procoagulant factor of leukemic promyelocytes: Demonstration of immunologic cross reactivity with human brain tissue factor. Br J Haematol 30: 151, 1975.

6) Gralnick HR, Sultan C. Acute promyelocytic leukemia: Haemorrhagic manifestation and morphologic criteria. Br J Haematol 29: 373, 1983.

7) Andoh K, Kubota $T$, Kobayashi N, Maekawa T. Radioimmunoassay of human tissue factor. Thromb Res 43: 275, 1986.

8) Andoh K, Sadakata H, Uchiyama T, et al. One-stage method for assay of tissue factor activity of leukemic cell with special reference to disseminated intravascular coagulation. Am J Clin Pathol 93: 679, 1990.

9) Andoh K, Kubota T, Takada M, Tanaka H, Kobayashi N, Maekawa T. Tissue factor activity in leukemia cells. Special reference to disseminated intravascular coagulation. Cancer 59: 748, 1987.

10) Lyberg T, Galdal KS. Evensen SA, Prydz H. Cellular cooperation in endothelial cell thromboplastin synthesis. Br J Haematol 53: 85, 1983.

11) Fibach E, Treves A, Korenberg A, Rachmilewitz EA. In vitro generation of procoagulant activity by leukemic promyelocytes in response to cytotoxic drugs. Am J Hematol 20: 257, 1985.

12) Tanaka $H$, Andoh $K$, Narahara $N$, et al. The leukocyte membrane and its contribution to thrombosis and haemostasis with special reference to tissue factor. Acta Haematologica Japonica 49: 119, 1986.

13) Bennett JM, Catovsky D, Daniel MT, et al. Proposals for the classification of the acute leukaemias. Br J Haematol 33: 451, 1976.

14) Lichtman MA, Brennan JK. Preleukemia and Oligoblastic Leukernia (Myelodysplastic Disorders). in: Hematology, Williams WJ, Beutler E, Erslev AJ, Lichtman MA, Eds. McGraw-Hill, New York, 1990, p. 175.

15) Lichtman MA. Chronic Myelogenous Leukemia and Related Disordets. in: Hematology, Williams WJ, Beutler E, Erslev AJ, Lichtman MA, Eds. McGraw-Hill, New York, 1990, p. 202.

16) Lichtman MA, Henderson ES. Acute Myelogenous Leukemia. in: Hematology, Williams WJ, Beutler E, Erslev AJ, Lichtman MA, Eds. McGraw-Hill, New York, 1990, p. 251.

17) Mauer AM. Acute Lymphocytic Leukemia. in: Hematology, Williams WJ, Beutler E, Erslev AJ, Lichtman MA, Eds. McGraw-Hill, New York, 1990, p. 994.

18) Silber R, Stahl R. Chronic Lymphocytic Leukemia and Related Diseases. in: Hematology, Williams WJ, Beutler E, Erslev AJ, Lichtman MA, Eds. McGraw-Hill, New York, 1990, p. 1005.

19) Kobayashi N, Maekawa T, Takada M, Gonmori H. Criteria for Diagnosis of DIC Based on the Analysis of Clinical and Laboratory Findings in 345 Patients Collected by the Research Committee on DIC in Japan. in: Disseminated Intravascular Coagulation, Abe T, Yamanaka M, Eds. University of Tokyo Press, Tokyo, 1983, p. 265.

20) Gonmori H, Takeda Y. Properties of canine tissue thromboplastins from brain, lung, arteries and veins. Am J Physiol 229: 619, 1975.

21) Osterud B, Bogwald J, Lindahl U, Seljelid R. Production of blood coagulation factor $\mathrm{V}$ and tissue thromboplastin by macrophages in vitro. Federation of European Biochemical Societies, Letters 127: 154, 1981.

22) Maier RV, Ulevitch RJ. The induction of a unique procoagulant activity in rabbit hepatic macrophages by bacterial lipopolysaccharides. J Immunol 127: 1596, 1981.

23) Tanaka H, Narahara N, Kurabayashi H, et al. Studies of leukemic cell tissue factor. Thromb Res 53: 535, 1989. 